\title{
Environmental quality of marginal territories using comparative analysis of fluctuating asymmetry methods and determining the area of leaf damage
}

\author{
Aleksander Lugovskoy ${ }^{1,2, *}$, Sergey Gildenskiold ${ }^{1}$, Tatjana Krylova ${ }^{1}$, Nina Fomina ${ }^{1}$ \\ ${ }^{1}$ Moscow Region State University, 10A, Radio str., 105005, Moscow, Russia \\ ${ }^{2}$ Moscow State University of Geodesy and Cartography, 4, Gorokhovsky Per., 105125, Moscow, \\ Russia
}

\begin{abstract}
The paper assess marginal and control territories within the Moscow Metropolitan area using a comparative analysis of fluctuating asymmetry method and determining the area of leaf damage to obtain a comprehensive assessment of the territory from the point of view of human habitation with minimal comfort parameters within the sensitivity of plants. The results of the combined analysis of two methods are obtained, which confirm the possibility of their use and the representativeness of the results obtained in assessing the comfort of the environment. The assessment of the quality of the environment in marginal territories was made by quantitative and qualitative indicators for the rational use of land resources, their involvement in economic turnover with the creation of favorable conditions for ensuring the flow of social processes of territorial development and comfortable life support of the population. It was proposed that socially-oriented infrastructure, leisure facilities, and social and cultural facilities have been formed in these territories with a sufficiently large and diverse number of types and forms of employment for the population, which should become the basis for the development of marginal territories.
\end{abstract}

\section{Introduction}

Assessment of the quality of the living environment can be carried out by quantitative and qualitative indicators, but the selection of criteria is the most problematic stage of assessing the condition of the environment. First of all, the problem is to identify the object of research when assessing the quality of the environment, namely, the question of whom to take as the basis of: a person or other living organisms [1-5]. Of course, the value of evaluation from the human point of view is the dominant task of research. However, latent tendencies that do not manifest in manifestation the processes cannot be recognized without analyzing the state of species that are more sensitive than humans. These include representatives of the plant kingdom, although there are discussions within it about

\footnotetext{
*Corresponding author: alug1961@yandex.ru
} 
choosing the most appropriate species from the point of view of research tasks, naming representatives of gymnosperms and lichens as the most suitable in comparison with angiosperms, and the use of woody life forms in comparison with herbaceous ones is more desirable from the point of view of increased sensitivity and use as indicators [6,7].

Assessment of territory is important from the point of view of land use and their involvement in economic circulation with the creation of favorable conditions to ensure the flow of social processes of territorial development and a comfortable livelihood resources to the extent which requires the Concept of sustainable development [8-19].

According to Makarychev A. S. [20] marginal territories are territories that have the potential for independent development, insubordination to dominant structures. Marginality - the marginal, borderline position of a natural formation, for example, a strip of semideserts and deserts. In environmental management and territorial administration, zones with signs of marginality are defined as zones where the average harvest of products makes it possible to pay for production costs, but it is not enough to pay rent. Based on the principle of vulnerability and specificity of zones, marginal territories are understood as peripheral zones where environmental management is complicated due to climate and soil quality, etc. At the end of the XX century, the volume of territories occupied by agricultural crops and forage-producing lands, as a result of the withdrawal of these territories from circulation. This gave rise to an increase in deposits. Removing them from the production cycle to a partial increase in deposits. Therefore, it is advisable to use them in agricultural production or refuse to use them in accordance with the needs of the economy.

The diversity of scientists involved in marginal zones - all this has led to the emergence of different approaches, in the understanding of the term "marginal territories". In general, "Marginal (marginal - side - on the fields), insignificant, minor, auxiliary" [21], and the marginal area is the territory where the cultural features of neighboring cultures are found, while the principle of exclusivity is used [22]. The basis of "marginality" is what plays the least role in the "mainstream" conditions. Sometimes these areas are very strongly affected by the results of this situation. Averina M. V. [23] defines marginal lands as a territory related to the term "ecotone", i.e. a territory located on the border between geo systems, a "stress zone", which has a sufficient length and is characterized by a higher compactness and diversity of localized species, which is called the "edge effect" and serves as a conductor of biological matter and energy flows between two ecological systems. The concept is based on the principle of tension between ecosystems. The rule for establishing a marginal zone is its contact or border state. Ecotones in the conditions of anthropogenic urbanized environment due to the variety of physical and geographical parameters have a high level of natural diversity and specific biological processes. They have the functional task of conserving natural diversity and greater resource opportunities within a city or suburb. Polygons of solid household waste, abandoned industrial zones, cut off from use rarely visited urban landscapes are considered marginal territories, comparable to the term "ecotone", have a large extent and are characterized by specific species located here due to the manifestation of the "edge effect". I.Petrasov, understanding marginal territories as unproductive lands, based the definition on the principle of land productivity and says that the productivity of these territories needs to change the direction of activity in these territories, for example, to develop eco-tourism, which will rationalize the use of these lands and increase income from them [24].

Landscape design shows the changes that occur on these lands under the influence of favorable or unfavorable factors of the natural habitat of the population, changing each other under the influence of economic, industrial and social reasons. Historical factors that influenced the development of these lands, as agricultural ones, have lost their significance. As a result of import substitution and intensification of agricultural production, many lowprofit lands were withdrawn from circulation. The formation of medium-sized cities takes 
place on marginal lands, while the formation of large-sized cities and their suburbs is going on due to the involvement of semi-marginal territories.

In our opinion, there cannot be one approach due to the diversity of natural components, the specificity of the set of environmental factors, and the multiplicity of tasks in a particular geo system. In connection with this goal, we have attempted to assess the territory of residence within the Moscow Metropolitan area using the tasks of comparative analysis of methods of fluctuating asymmetry and determining the area of leaf damage to obtain a comprehensive assessment of the territory from the point of view of human residence with minimal comfort parameters within the sensitivity of plants.

\section{Materials and methods of the research}

The methodology for assessing the condition of the environment based on the results of measuring leaf asymmetry is based on the theory developed by V. M. Zakharov and A.V. Yablokov [25,26]. It is used to assess the ecological condition of the area based on the asymmetry of tree leaves. The collection of leaves began at the end of their formation and before they wither or start leaf fall. Leaves were taken from two or three plants, in the amount of thirty pieces. They are collected from the lower parts of trees, at the height of the raised hand. Leaves from one tree were collected in a package and signed.

The material that has been collected is processed immediately until the leaves have wilted. The measurements were performed using the standard method for estimating fluctuations in five parameters with the calculation of the relative asymmetry index using the formula (1) followed by the calculation of the integral indicator of development stability:

$$
\frac{\mid \text { left-right } \mid}{\text { left+right } \mid}
$$

To do this, calculate the arithmetic mean for the sample of leaves. The obtained indicators are compared with the values from the table, and determine the degree of transformation on the test polygon of the condition of the environment.

The method of zoning the territory based on the results of measuring the area of damage to vegetative organs of plants, in general, and the leaf surface, in particular, is used to assess the condition of the environment. At the selected site, leaf collection began from the moment of plant formation and growth until the beginning of fall. Leaves were selected from 2-3 plants growing in different environmental conditions, in an amount of 28 pieces. They are collected from the lower parts of trees, at the height of the raised hand. Leaves from one tree are collected in a package and signed it. The collected material is dried to work with them in the autumn-winter period. To study the material that has been collected, a compass or ruler, pencil and sheets in a cage are used. First set the area of the sheet according to the formula 2 :

$$
S_{\text {leaf }}=\frac{\mathrm{P}_{\text {leaf } * S_{s q}}}{\mathrm{P}_{s q}}
$$

where: $\mathrm{P}_{\text {leaf }}$ - leaf and $\mathrm{P}_{s q}$ - square of paper, $\mathrm{S}_{s q}$-square of paper.

Then the conversion coefficient was calculated using the formula (3) based on the measurement of 7 leaf plates:

$$
\mathrm{K}=\frac{s_{\text {leaf }}}{S_{\text {sq }}}
$$

After measuring the length (A) and width (B) of the leaf plate, we multiply using a conversion coefficient, and get the area of the leaf (4) in a clean or polluted zone. 


$$
S=A * B * K
$$

At the final stage, we calculate the arithmetic value of the area of the leaf for the selection from this polygon. To get this indicator, we sum all the obtained values by leaf area and divide by the number of leaves. The sampling locations of marginal zones (orange) and control points (green) within the Moscow Metropolitan area for analysis using appropriate methods are shown in figure 1.

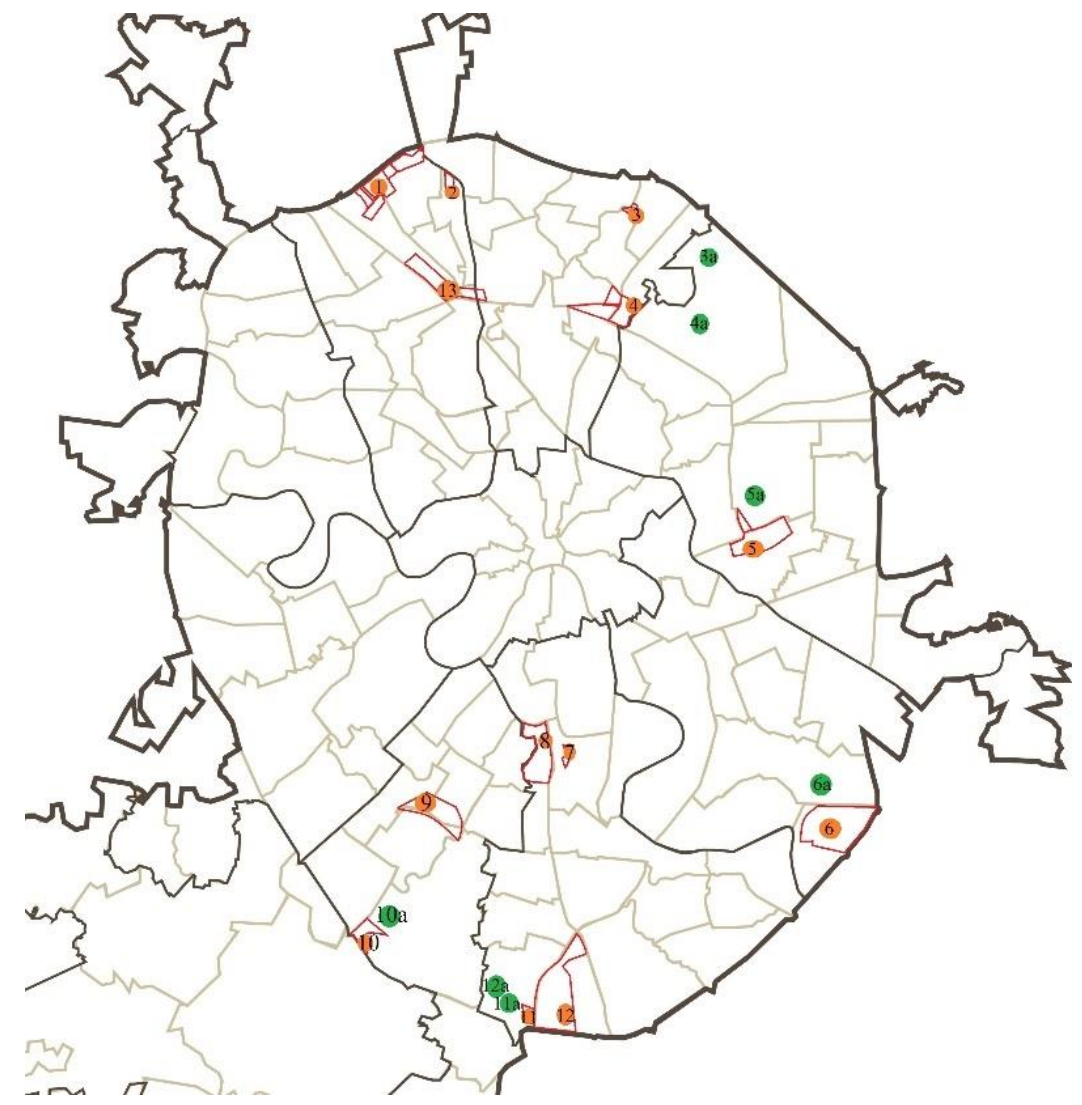

Fig. 1. Locations of polygons of the research and sampling sites.

The research was started with defining polygons of the research and classifying them by type of organizational measures to optimize the environment and engage in social turnover. Before proceeding to the description and sampling, we gave a geo-botanical description of the selected polygon, indicating the location of the polygon on the locality and the nature of the terrain (for example, on a plain, on a slope to a stream or ravine, on the river bank, etc.), as well as noting the features of its environment (swamp, meadow, road or other anthropogenic object, etc.). The community was designated based on the predominant plant species in each of the community levels. However, the names of species within each level were indicated based on an increase in their comparative number. The final name of the community consists of several parts - tree level, shrub level, and grass and small shrub level. The research site was laid out in the size of 20x20 meters. Descriptions began with the study of the closeness of the crowns and its projection on the surface area of the earth, which is covered by the shadows of the branches. The description of crown closeness was performed according to 3 criteria: in percentage (from 0 to 100), in point (from 1 to 5 or 10 ), and in proportion (from 0.1 to 1 ). Closeness for each of the levels (wood, young trees 
and the undergrowth), this criterion is determined separately. Then we determined the stand formula and the description of the share of each individual species in each level of the stand. For this indicator, the description was conducted in a point system from 1 to 10 . The total volume of vegetation is taken as 10 , and it is studied what proportion belongs to each specific species. Those species that, according to the number of individuals, did not reach 1 point, are marked with a "+" sign, and those species that are single with a "unit" sign. Plants in the formula are called by the first two letters. When analyzing vegetation, the bonitet was determined by measuring the trunk diameter at the level of $1.3 \mathrm{~m}$, the height of the tree and the age of the plants. To characterize abiotic factors of natural and man-made origin, a physical and geographical description of polygons of the research area was performed.

\section{Results and discussion of the research}

The analysis made it possible to identify the degree of contribution of each factor and its parameter to the overall level of assessment of the ecological condition of the territory where the population lives (table 1). To identify specific and universal factors of influence within the megalopolis, the transport load was taken into account; the features and nature of architectural structures that determine regional micro-features of lighting and wind conditions to ensure inversion of temperatures and pollutants; the presence of parking areas determines the nature of the speed regime and the intensity of pollutants entering the atmosphere as a factor of influence on roadside vegetation; the nature and types of plantings and proximity to transport highways as a factor of reducing the level of exposure of pollutants; individual-specific characteristics of gas resistance of plants, changing depending on the species and the stage of passing the phenological phase of development; registration of the degree and nature of damage in the form of chlorosis and necrosis under the influence of both abiotic factors and damage as a result of biotic relationships in the form of manifestation of symptoms of diseases and insect bites. Studies have shown variation both within marginal zones and within control points. However, there is a steady significant difference in the degree of variation between the control and experimental polygons of the research, while the tendency manifests to optimize the conditions with a decrease in the nature of the impact in the conditions designated as control.

Table 1. Characteristics of the condition of the roadside forest lines industrial marginal areas and control sites.

\begin{tabular}{|c|c|c|c|c|c|}
\hline $\begin{array}{c}\text { Indicator } \\
\text { parameter }\end{array}$ & $\begin{array}{c}\text { "Kapotnya" } \\
\text { industrial } \\
\text { zone }\end{array}$ & $\begin{array}{c}\text { "Kuzminki" } \\
\text { Control }\end{array}$ & $\begin{array}{c}\text { "Vagonoremont" } \\
\text { industrial zone }\end{array}$ & $\begin{array}{c}\text { "Ostashkovskoo } \\
\text { shosse" } \\
\text { industrial zone }\end{array}$ & $\begin{array}{c}\text { "Losiny } \\
\text { Ostrov" } \\
\text { Control }\end{array}$ \\
\hline $\begin{array}{c}\text { Lighting } \\
\text { conditions }\end{array}$ & Solar & Shadow & Shadow & Shadow & Shadow \\
\hline $\begin{array}{c}\text { Type of } \\
\text { transport }\end{array}$ & $\begin{array}{c}\text { Cargo and } \\
\text { passenger } \\
\text { cars }\end{array}$ & $\begin{array}{c}\text { Passenger } \\
\text { transport and } \\
\text { buses }\end{array}$ & $\begin{array}{c}\text { Cargo and } \\
\text { passenger cars }\end{array}$ & $\begin{array}{c}\text { Passenger } \\
\text { cars }\end{array}$ & No \\
\hline $\begin{array}{c}\text { Tallest } \\
\text { building }\end{array}$ & $\begin{array}{c}\text { High-rise } \\
\text { industrial } \\
\text { buildings }\end{array}$ & No & $\begin{array}{c}\text { High-rise } \\
\text { industrial } \\
\text { buildings }\end{array}$ & $\begin{array}{c}\text { High-rise } \\
\text { industrial } \\
\text { buildings }\end{array}$ & No \\
\hline $\begin{array}{c}\text { Presence of } \\
\text { blowouts } \\
\text { between } \\
\text { buildings }\end{array}$ & Present & No & Present & Present & No \\
\hline $\begin{array}{c}\text { Availability } \\
\text { of parking } \\
\text { zones }\end{array}$ & $\begin{array}{c}\text { Parking lots } \\
\text { for cargo } \\
\text { transport }\end{array}$ & Bus stop & $\begin{array}{c}\text { Parking lots for } \\
\text { cargo transport }\end{array}$ & No & No \\
\hline
\end{tabular}




\begin{tabular}{|c|c|c|c|c|c|}
\hline $\begin{array}{l}\text { Proximity of } \\
\text { plantings to } \\
\text { the road }\end{array}$ & Close & Remote & Close & Close & Remote \\
\hline $\begin{array}{l}\text { Type of } \\
\text { plantings }\end{array}$ & $\begin{array}{l}\text { Protective } \\
\text { two lane } \\
\text { landing } \\
\end{array}$ & Park & $\begin{array}{l}\text { Protective single- } \\
\text { lane landing }\end{array}$ & $\begin{array}{l}\text { Protective } \\
\text { single-lane } \\
\text { landing } \\
\end{array}$ & $\begin{array}{l}\text { Forest } \\
\text { park }\end{array}$ \\
\hline $\begin{array}{l}\text { Sustainable } \\
\text { wood } \\
\text { species }\end{array}$ & $\begin{array}{l}\text { The most } \\
\text { unstable } \\
\text { American } \\
\text { maple, stable- } \\
\text { aspen and } \\
\text { oak. }\end{array}$ & $\begin{array}{c}\text { The most } \\
\text { stable are } \\
\text { apple and } \\
\text { maple trees. } \\
\text { The most } \\
\text { unstable - } \\
\text { poplar. }\end{array}$ & $\begin{array}{l}\text { The most stable } \\
\text { are birch and } \\
\text { oak. Unstable } \\
\text { rock-ash. }\end{array}$ & $\begin{array}{l}\text { Resistant- } \\
\text { holly maple. } \\
\text { Not stable- } \\
\text { American } \\
\text { maple and } \\
\text { linden. }\end{array}$ & $\begin{array}{l}\text { The most } \\
\text { unstable } \\
\text { breeds are } \\
\text { linden and } \\
\text { maple }\end{array}$ \\
\hline $\begin{array}{c}\text { Phenological } \\
\text { phase }\end{array}$ & $\begin{array}{l}\text { Fruit } \\
\text { ripening. }\end{array}$ & Ripe fruit & Fruit ripening & $\begin{array}{l}\text { Fruit } \\
\text { ripening }\end{array}$ & $\begin{array}{l}\text { Ripe } \\
\text { fruit }\end{array}$ \\
\hline $\begin{array}{c}\text { The } \\
\text { presence of } \\
\text { chlorosis, } \\
\text { the } \\
\text { percentage } \\
\text { of damaged } \\
\text { tissue }\end{array}$ & $\begin{array}{l}\text { Chlorosis on } \\
\text { the leaves of } \\
\text { the American } \\
\text { maple along } \\
\text { the main vein. }\end{array}$ & No & $\begin{array}{l}\text { The presence of } \\
\text { chlorosis on the } \\
\text { leaves of the ash, } \\
\text { and the bottom } \\
\text { crown } 3 \% \text {. }\end{array}$ & $\begin{array}{c}\text { Chlorosis of } \\
\text { American } \\
\text { maple leaves } \\
\text { on the veins } \\
70 \% .\end{array}$ & $\begin{array}{c}\text { Spot } \\
\text { chlorosis } \\
\text { on maple } \\
\text { leaves, } \\
\text { the } \\
\text { middle } \\
\text { part of } \\
\text { the } \\
\text { crown. }\end{array}$ \\
\hline $\begin{array}{l}\text { Presence of } \\
\text { necrosis, } \\
\text { percentage }\end{array}$ & No & $\begin{array}{c}\text { Spot necrosis } \\
\text { on poplar } \\
\text { leaves. }\end{array}$ & $\begin{array}{l}\text { Ash leaves have } \\
\text { marginal and inter- } \\
\text { venous necrosis. }\end{array}$ & $\begin{array}{l}\text { Spot necrosis } \\
\text { on leaves of } \\
\text { linden }\end{array}$ & $\begin{array}{c}\text { Point } \\
\text { necrosis, } \\
\text { linden } \\
\text { leaves }\end{array}$ \\
\hline $\begin{array}{l}\text { Damage by } \\
\text { pests and } \\
\text { diseases }\end{array}$ & No & No & $\begin{array}{c}\text { Horse chestnut } \\
\text { leaves are } \\
\text { affected by } \\
\text { chestnut mining } \\
\text { moth. }\end{array}$ & $\begin{array}{c}\text { Linden } \\
\text { leaves are } \\
\text { damaged by } \\
\text { linden leaf } \\
\text { blotch miner } \\
\text { moths. }\end{array}$ & $\begin{array}{c}\text { Linden } \\
\text { leaves } \\
\text { are } \\
\text { damaged } \\
\text { by linden } \\
\text { gall } \\
\text { mite. }\end{array}$ \\
\hline
\end{tabular}

A comparative study of the leaf surface asymmetry of the two most common tree species used both for landscaping and growing as undergrowth in the natural nature of renewal, and the level of pollution allowed us to obtain a five-point scale for the comfort conditions of the study area (table 2).

Table 2. Point gradation of the environment condition by the fluctuating asymmetry parameter.

\begin{tabular}{|c|c|c|c|c|c|}
\hline \multirow{2}{*}{ Type } & \multicolumn{5}{|c|}{ Points } \\
\hline & 1 & 2 & 3 & 4 & 5 \\
\hline Betula verrucosa & $\begin{array}{c}< \\
0.039 \\
\end{array}$ & $0.04-0.0449$ & $\begin{array}{c}0.0451- \\
0.0489\end{array}$ & $0.051-0.0539$ & $>0.0541$ \\
\hline Tilia cordata & $\begin{array}{c}< \\
0.0019\end{array}$ & $0.002-0.0089$ & $\begin{array}{c}0.0091- \\
0.0219\end{array}$ & $0.0221-0.039$ & $>0.041$ \\
\hline
\end{tabular}

Note: condition of the environment: 1-no pollution; 2-relatively clean pollution within the norm 3-moderate pollution above the norm; 4-heavily polluted; 5 -very heavy pollution - it is dangerous.

The results were used to obtain indicators for each specific marginal zone. As a result of processing the results obtained in the course of conducting field studies using two coupled methods, table 3 was compiled. 
Table 3. Results of statistical research of leaves by three indicators.

\begin{tabular}{|c|c|c|c|}
\hline No & Marginal and control territories & $\begin{array}{c}\text { The measure of } \\
\text { fluctuating } \\
\text { asymmetry of the } \\
\text { leaf }\end{array}$ & $\begin{array}{c}\text { The area of leaf surface } \\
\text { lesion in the marginal } \\
\text { and control zones }\end{array}$ \\
\hline 1 & "Korovino" industrial zone & 0.0439 & 15.93 \\
\hline 2 & "Teply stan" industrial zone & 0.0248 & 55.50 \\
\hline 3 & "Bitsevsky forest park" Control & 0.049 & 20.96 \\
\hline 4 & "Biryulyovo" industrial zone & 0.0599 & 36.93 \\
\hline 5 & "Bitsevsky forest park" Control & 0.0328 & 16.20 \\
\hline 6 & "Prozhektor" industrial zone & 0.0437 & 8.53 \\
\hline 7 & "Izmailovsky forest park" Control & 0.0387 & 10.63 \\
\hline 8 & "Kapotnya" industrial zone & 0.0911 & 19.64 \\
\hline 10 & "Kuzminki" Control & 0.0356 & 64.01 \\
\hline 11 & "Vagonoremont" industrial zone & 0.0309 & 27.02 \\
\hline 12 & "Losiny Ostrov" Control & 0.0487 & 9.22 \\
\hline 13 & "Verkhnie kotly" industrial zone & 0.0181 & 40.66 \\
\hline 14 & "Nagatino" industrial zone & 0.0491 & 18.31 \\
\hline 15 & "Vorontsovo" industrial zone & 0.0408 & 18.79 \\
\hline 16 & "Bitsevsky forest park" Control & 0.0481 & 16.02 \\
\hline 17 & "Degunino-Likhobory" industrial & 0.0322 & 16.16 \\
\hline 18 & "Severyanin" industrial zone & 0.0431 & 11.38 \\
\hline 19 & "Losiny Ostrov" Control & 0.023 & 15.93 \\
\hline 20 & "Krasny stroitel" industrial zone & 0.0133 & 40.66 \\
\hline 21 & "Bitsevsky forest park" Control & 0.0331 & 47.86 \\
\hline
\end{tabular}

The decrease in fluctuating asymmetry is associated with an increase in the index of damage to the leaf surface in marginal zones, and the trend was also observed in control points, but it was most pronounced in them. Despite the differences caused by the manifestation of the characteristics of plant individuals and an individual set of territory factors, the combined use of two bio-indication methods allowed for their mutual correction and verification. Ranking of data on the basis of leaf surface damage confirms the fact that a large volume of territories has a low percentage of leaf tissue damage, which indicates a high resistance of plants to pollution, and the ability of these plants to improve the quality of the environment.

\section{Conclusion}

The assessment of the comfort of the environment was carried out on the basis of a comparative analysis of coupled methods of fluctuating asymmetry and determining the area of leaf damage under the influence of atmospheric pollutants gave positive results for recommendations in their use. Ranking of data on indicators of fluctuating asymmetry indicates a large variability of this feature, which in turn indicates that this indicator is closely related to the anthropogenic impact on the environment. The prepared map of marginal territories will allow to carry out organizational measures in these territories in order to optimize their habitat and involve them in social and economic turnover, depending on the recommendations for further reorganization of these territories to optimize the condition of the environment.

One of the main moments of reducing negative manifestations in solving this problem is to increase the cultural, social and economic level of the population of these territories. It is 
necessary that social and cultural objects are formed in these territories and this should become the basis for the development of marginal areas. The main criterion for this should be the ability to self-actualize, which requires in these areas the availability of a sufficient number of types and forms of employment for the population. One of the conditions for the development of these territories is the creation of socially-oriented infrastructure and leisure facilities for the development of high-quality preschool and school education. Wellorganized social work is one of the indicators of these territories' exit from the category of marginal areas, and this approach, as a rule, will allow changing the attitude of the population to their place of residence.

\section{References}

1. M.V. Averina, The concept of marginality as a tool for analyzing social and cultural dynamics. dissertation: 24.00 .01 (2015)

2. L.A. Lugovskaya, A.V. Zemlyakova, L.A. Mezhova, A.M. Lugovskoy, Scientific Bulletin of the Belgorod State University: natural sciences 18(239)-36, 87 (2016)

3. A.M. Lugovskoy, G.M. Mainasheva, M.I. Podbolotova, L.A. Lugovskaya, L.A. Mezhova, G.N. Chernyatina, Problems of regional ecology 3, 112 (2013)

4. A.S. Makarychev, Electronic journal: cultural and humanitarian geography 2(1) (2012) https:/gumgeo.ru/index.php/gumgeo/issue/view/2

5. Agenda for the 21st century: Chapter 14. Promotion of sustainable agriculture and rural development (1992) http://www.spsl.nsc.ru/win/nelbib/agenda21_rus/ch14.htm

6. Glossary.ru, http://www.glossary.ru/ cgi-bin/g1_sch2.cgi?R1dMgwmg

7. Encyclopedia of sociology, http://dic.academic.ru/dic.nsf/socio/ 1108/\%D0\%97\%D0\%9E\%D0\%9D\% D0\%90

8. V.S. Zaletaev, Structural organization of ecotones in the context of ecotones management (Moscow, RAAS, 1997)

9. Marginal lands, Dictionaries and encyclopedias on Akademik (1997) http://big_economic_dictionary.academic.ru/4903

10. B.M. Mirkin, L.G. Naumova, Short course of general ecology. Part 2: ecology of ecosystems and biosphere: 15.6.2. Ecosystem level (Ufa, BSPU Publishing house, 2011)

11. A.N. Nikolskaya, A..I Fedorova, Workshop on ecology and environmental protection (Moscow, Vlados, 2001)

12. Perspective description of mountain territories, http://pandia.ru/text/77/153/15032.php

13. Plan of physical and geographical characteristics, Ecological and social project "Malaya Rodina", http://www.unnat.ru/eco/geo.htm

14. The concept of land resources of Russia, http://works.doklad.ru/view/ zKm8XLXFMu4/all.html

15. Consequences of climate change for regions: vulnerability assessment, Russian archipelago (1997) http://www.archipelag.ru/agenda/ geoklimat/history/consequences

16. I.A. Ryaposov, Youth and science: collection of materials of the X Anniversary allRussian scientific and technical conference of students, postgraduates and young scientists with international participation, dedicated to the $80^{\text {th }}$ anniversary of the Krasnoyarsk territory formation (Krasnoyarsk, Siberian Federal University, 2014)

17. N. Tulebayeva, D. Yergobek, G. Pestunova, A. Mottaeva, Z. Sapakova, E3S Web of Conferences 159, 01012 (2020) https://doi.org/10.1051/e3sconf/202015901012 
18. The phenomenon of marginality in the modern world: theoretical approaches and possible solutions, Scientific papers of Kazakhstan, http://articlekz.com/article/5253

19. Effective management of marginal lands to improve the winter feed production system and diversify rural incomes, http://cac-program.org/ru/news/detail/479

20. A.S. Makarychev, Electronic journal: cultural and humanitarian geography 2(1) (2012) https://gumgeo.ru/index.php/gumgeo/issue/view/2

21. T. Simankina, I. Kibireva, A. Mottaeva, M. Gusarova, Advances in Intelligent Systems and Computing 983, 138 (2019) https://doi.org/10.1007/978-3-030-19868-8_13

22. A. Mottaeva, A. Ivashchenko, A. Ryattel, E3S Web of Conferences 164, 10038 (2020) https://doi.org/10.1051/e3sconf /202016410038

23. M.V. Averina, The concept of marginality as a tool for analyzing socio-cultural dynamics, dissertation: 24.00.01 (2015)

24. I. Petrasov, Concept of sustainable development in relation to world tourism: Chapter 3: Sustainability as a priority direction of tourism development in the $21^{\text {st }}$ century. All about tourism, http://tourlib.net/books_tourism/petrasov2-3.htm

25. A.I. Zyryanov, Geographical Bulletin 2 (2008)

26. V.N. Lavrova, A.G. Muravjev, N.A. Pugal, Ecological workshop. Textbook (Saint Petersburg, Crismas + , 2003)

27. E. Ganebnykh, T. Burtseva, A. Petukhova, and A. Mottaeva, E3S Web of Conferences 91, 08035 (2019) DOI: 10.1051/e3sconf /201991080 